JURNAL ILMIAH
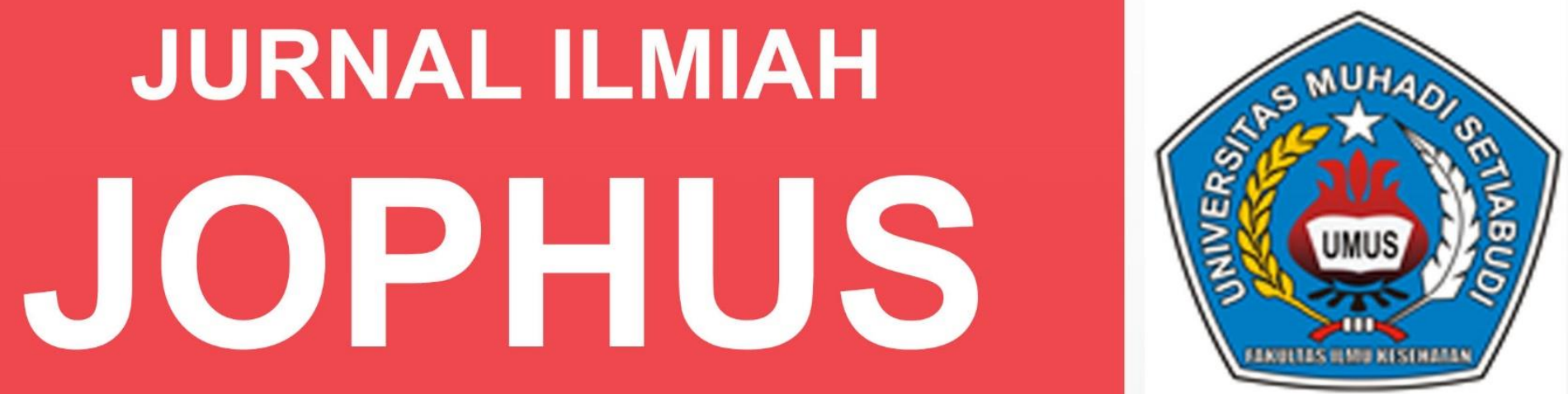

\title{
Journal of Pharmacy Umus
}




\section{KATA PENGANTAR}

\section{Assalamualaikum $\mathrm{Wr}, \mathrm{Wb}$}

Puji syukur kehadirat Allah SWT atas anugrah-Nya sehingga jurnal edisi kali ini dapat terbit. Sebelumnya kami ingin mengucapkan terimakasih banyak kepada dosen/peneliti/profesi yang telah mengirimkan artikelnya kepada dewan redaksi untuk dapat dipublish pada jurnal yang kami kelola. Semua artikel yang masuk kepada dewan redaksi telah melalui proses review oleh mitra bestari dan tim dewan redaksi, segala proses revisi dan redaksional juga telah dilakukan oleh penulis sebelum jurnal ini diterbitkan. Segala bentuk kritik dan saran yang membangun dari pembaca / peneliti yang dikirimkan sangat kami harapkan demi melakukan pembenahan jurnal yang kami kelola. Akhir kata kami menghaturkan terimakasih banyak kepada semua pihak yang sudah terlibat dalam proses penerbitan jurnal ini.

Wassalamualaikum wr wb. 


\section{DAFTAR ISI}

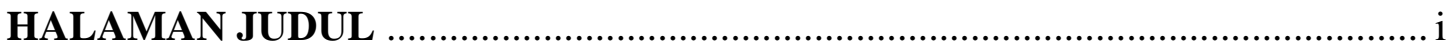

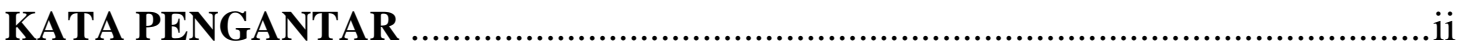

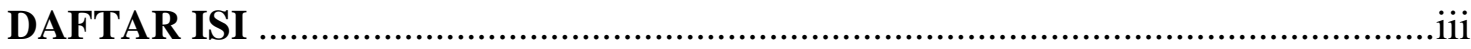

Uji Waktu Alir Granul Pati Sukun Dengan Metode Granulasi Basah Ririn N.F ${ }^{1}$, Yuniarti Dewi R*2), Rifqi Ferry B ${ }^{3)}$

${ }^{(1), 3)}$ Program Studi Farmasi, Fakultas Ilmu Kesehatan, Universitas Muhadi Setiabudi Brebes

${ }^{2)}$ Program Studi Ilmu Gizi, Fakultas Ilmu Kesehatan, Universitas Muhadi Setiabudi Brebes) 1-4

Evaluasi Pelayanan Obat Non Resep Di Apotek Manjur Desa Petunjungan

Devi Mustika $^{1)}$, Hanari Fajarini*2), Tya Muldiyana ${ }^{3)}$

(1),2),3)Program Studi Farmasi, Fakultas Ilmu Kesehatan, Universitas Muhadi Setiabudi Brebes) 5-12

Uji Kompresibilitas Granul Pati Bengkoang Dengan Metode Granulasi Basah Jamah Yulisani $^{1}$, Rifqi Ferry Balfas ${ }^{2}$, Hanari Fajarini ${ }^{3)}$

${ }^{\left({ }^{1), 2}\right)}$ Program Studi Farmasi, Fakultas Ilmu Kesehatan, Universitas Muhadi Setiabudi Brebes)

Uji Daya Serap Air Granul Pati Kentang Dengan Metode Granulasi Basah

Meisintya De $\mathrm{Nanda}^{1}$, Rifqi Ferry B*2)

${ }^{(1), 2)}$ Program Studi Farmasi, Fakultas Ilmu Kesehatan, Universitas Muhadi Setiabudi Brebes

Uji Mutu Sabun Dengan Subsitusi Bubuk Daun Kelor Sabila Rosyidah ${ }^{1)}$, Yuniarti Dewi R*2), Rifqi Ferry B ${ }^{3)}$

${ }^{(1,3)}$ Program Studi Farmasi, Fakultas Ilmu Kesehatan, Universitas Muhadi Setiabudi Brebes

${ }^{2}$ Program Studi Ilmu Gizi, Fakultas Ilmu Kesehatan, Universitas Muhadi Setiabudi Brebes)

Formulasi Sediaan Sabun Cair Dari Ekstrak Daun Bidara Arab (Ziziphus Spina-Christi L)

Gina Lestari ${ }^{1)}$, Ike Suciati ${ }^{2}$, Herlina ${ }^{3)}$

${ }^{(1), 2), 3)}$ Program Studi Farmasi, Akademi Farmasi Al-Fatah Bengkulu) 


\title{
FORMULASI SEDIAAN SABUN CAIR DARI EKSTRAK DAUN BIDARA ARAB (ZIZIPHUS SPINA-CHRISTI L)
}

\author{
Gina Lestari*1 ${ }^{* 1}$ Ike Suciati ${ }^{2}$, Herlina ${ }^{3}$ \\ 1,2,3Program Studi Farmasi, Akademi Farmasi Al-Fatah Bengkulu, Indoensia \\ Email: ghinafathur@gmail.com
}

\begin{abstract}
ABSTRAK
Daun bidara arab atau yang dikenal dengan nama ilmiah Ziziphus Spina-christi L. merupakan tanaman yang telah umum digunakan pada traditional chinese medice untuk mengobati infeksi kulit hal ini dikarenakan daun bidara arab memiliki kandungan alkaloid, flavonoid dan tanin yang berfungsi sebagai antibakteri. Sampel yang digunakan dalam penelitian adalah daun bidara arab yang di ekstraksi dengan cara maserasi kemudian diuap kan dengan water bath. Ekstrak dibuat dalam tiga formula (F1, F2, F3) dengan komposisi minyak zaitun, $\mathrm{KOH}$, asam stearat, $\mathrm{CMC}$, SLS, nipagin, nipasol, pengaroma, aquadest serta ekstrak daun bidara arab dengan variasi konsentrasi $1 \%, 3 \%, 5 \%$. Evaluasi yang dilakukan yaitu uji organoleptis (bentuk, bau, warna), uji pH, uji tinggi busa, uji hedonik (bentuk, aroma, warna), uji viskositas. Hasil formulasi sedian sabun cair ekstrak daun bidara arab menunjukan bahwa daun bidara arab (Ziziphus Spina-christi L.) dapat di buat sabun cair dengan memvariasikan berbagai kadar ekstrak etanol daun bidara arab (Ziziphus Spina-christi L.) serta disimpulkan bahwa formula kedua adalah formula yang terbaik.
\end{abstract}

Kata kunci: Sabun Cair, Ekstrak Daun Bidara

\begin{abstract}
Bidara Arab leaf, also known by the scientific name Ziziphus Spina-christi L. is a plant that has been commonly used in traditional Chinese medice for treating skin infections this matter because arabic bidara leaves contain alkaloids, flavonoids and tannins that serves as an antibacterial. The samples used in the study are the leaves bidara arabic is extracted by maceration then steamed right with a water bath. Extracts made in three formulas (F1, F2, F3) with the composition of olive oil, $\mathrm{KOH}$, stearic acid, $C M C$, SLS, nipagin, nipasol, pengaroma, distilled water and leaf extract bidara arab with various concentrations of 1\%, 3\%, 5\%. Evaluations are conducted organoleptic test (shape, smell, color), test the $\mathrm{pH}$, foam height test, hedonic test (shape, scent, color), viscosity test
\end{abstract}

Keywords: liquid soap, Bidara Leaf Extract

\section{PENDAHULUAN}

Kulit menutupi permukaan tubuh dan memiliki fungsi utama sebagai pelindung tubuh dari berbagai gangguan dan rangsangan luar [1]. Kulit merupakan pertahanan utama terhadap bakteri dan apabila kulit tidak lagi utuh, maka menjadi sangat rentan terhadap infeksi. Infeksi disebabkan oleh bakteri, virus, protozoa, jamur, dan beberapa kelompok minor lainnya [2].

Bentuk sediaan farmasi yang dapat digunakan menjaga kesehatan kulit salah satunya ialah sabun. Sabun merupakan produk yang dihasilkan dari reaksi antara asam lemak dengan basa kuat yang berfungsi untuk mencuci dan membersihkan lemak (kotoran) [3]. Selain dapat membersihkan kulit dari kotoran, sabun juga dapat digunakan untuk membebaskan kulit dari bakteri. Sabun yang dapat membunuh kuman disebut dengan antiseptik dan harus memiliki 
standar khusus yaitu, pertama sabun harus dapat menyingkirkan kotoran dan bakteri. Kedua, sabun tidak merusak kulit, karena kulit yang sehat adalah bagian dari sistem kekebalan tubuh [4]. Sabun cair dibuat melalui saponifikasi dengan menggunakan minyak jarak dengan alkali (KOH). Untuk meningkatkan kejernihan sabun dapat ditambahkan gliserin atau alkohol [5].

Salah satu tanaman yang dapat digunakan ialah tanaman bidara arab yang memiliki nama ilmiah Ziziphus spina-cristi L. Bidara arab telah umum digunakan pada Traditional Chinese Medice untuk mengobati berbagai penyakit salah seperti gangguan pencernaan, infeksi kulit, diare, kanker, demam [6]. Tanaman bidara arab banyak ditemukan di Indonesia. Senyawa yang terkandung dalam tanaman ini yaitu flavonoid, alkaloid, triterpenoid, saponin, tanin lipid, dan protein. Hal ini juga dikuatkan berdasarkan penelitian dari Kusriani [7] diketahui bahwa ekstrak daun bidara arab dengan pelarut etanol mengandung alkaloid, flavonoid, saponin, tanin, kuinon, dan steroid/triterpenoid. Berdasarkan latar belakang diatas, maka penelitian ini akan memanfaatkan tanaman daun bidara arab dengan cara memformulasikannya menjadi “ formulasi sediaan sabun cair dari ekstrak bidara arab ( Ziziphus spina-christi L).

\subsection{Alat dan Bahan}

\section{METODE PENELITIAN}

Alat-alat yang digunakan dalam penelitian ini adalah batang pengaduk, waterbath, cawan penguap, beker glas, erlenmeyer, pipet tetes, blender, timbangan analitik, botol kaca gelap. Bahan-bahan yang digunakan dalam penelitian ini adalah ekstrak daun bidara arab, Minyak Zaitun, etanaol 70\%, KOH (kalium hidroksida), As.stearat, CMC (carboksil methyl selulosa), SLS (sodium lauril sulfat), Nipagin, Nipasol, Pengaroma, Aquadest

\subsection{JalannyaPenelitian Pengambilan sample}

Dalam pengumpulan sampel, peneliti mengambil sampel daun bidara arab (Ziziphus spinachristi L.) di daerah Bengkulu. Bagian yang diambil yaitu daun yang segar.

\section{Proses ekstrasi dengan metode maserasi}

Simplisia daun bidara arab yang telah kering sebanyak 250 gram lalu masukan kedalam wadah botol berwarna gelap yang tertutup dan tambahkan cairan penyari atau pelarut yaitu etanol $70 \%$ sebanyak 2 Liter mengunakan perbandingan antara sampel dan pelarut adalah (1:7.5), ditutup dan dikocok secara berulang sehingga pelarut masuk ke seluruh permukaan simplisia. Lakukan perendaman selama 6 hari, dengan beberapa kali dilakuan pengocokan dan pergantian pelarut, Hasil dari maserasi di masukan dalam rotary evaporator dengan putaran $70 \mathrm{rpm}$ dan suhu $70^{\circ} \mathrm{C}$ untuk memisahkan zat aktif dari pelarutnya sampai mengental.

\section{Proses pembuatan sabun cair}

Larutan $\mathrm{KOH}$ sebanyak 8gram masukan ke dalam $16 \mathrm{ml}$ aquadest sedikit demi sedikit, aduk hingga larut. Setelah larut simpan di tempat aman dengan suhu ruangan hingga larutnya berubah menjadi jernih.

1. Bahan-bahan yang telah disiapkan ditimbang sesuai dengan formula.

2. Asam stearat dan nipasol dilebur, CMC dan SLS di larutkan terlebih dahulu kedalam air panas pada wadah yang berbeda.

3. Pamanaskan minyak lalu masukkan larutan $\mathrm{KOH}$, masukkan $\mathrm{CMC}$ aduk hingga terbentuk massa sabun.

4. Setelah terbentuk massa sabun, ditambahkan asam stearat dan nipasol kedalamnya diaduk hingga larut, tambahkan nipagin diaduk hingga larut. Setelah larut ditambahkan SLS, 
pengaroma dan ekstrak daun bidara arab sambil diaduk kembali hingga homogen, larutan diaduk terus menerus dengan cepat hingga terbentuk larutan yang kental.

5. Pada larutan kental tersebut, kemudian tambahkan aquadest hingga volume $50 \mathrm{ml}$.

Tuang hasil sabun kedalam wadah bersih yang telah disiapkan, lalu tutup wadah sabun agar bebas dari udara luar.

Rangkuman mengenai kandungan dan bahan pembuatan sabun cair trdapat pada Table 1 .

Table 1. Formulasi sediaan sabun cair dari ekstrak daun bidara arab (ziziphus spina-christi.L)

\begin{tabular}{|c|c|c|c|c|c|}
\hline \multirow[b]{2}{*}{ Bahan } & \multicolumn{4}{|c|}{ Komposisi (\%) } & \multirow[b]{2}{*}{ khasiat } \\
\hline & F0 & F1 & F2 & F3 & \\
\hline Ekstrak daun bidara & 0 & 1 & 3 & 5 & Zat aktif \\
\hline Minyak Zaitun & 15 & 15 & 15 & 15 & Pelembut \\
\hline $\mathrm{KOH}$ & 8 & 8 & 8 & 8 & Pembentuk sabun \\
\hline Asam stearat & 0,25 & 0,25 & 0,25 & 0,25 & Zat tambahan \\
\hline CMC & 0,19 & 0,19 & 0,19 & 0,19 & Pengemulsi \\
\hline SLS & 0,5 & 0,5 & 0,5 & 0,5 & Pembusa \\
\hline Nipagin & 0,12 & 0,12 & 0,12 & 0,12 & Pengawet \\
\hline Nipasol & 0,1 & 0,1 & 0,1 & 0,1 & Pengawet \\
\hline Parfum & Qs & Qs & Qs & Qs & Pengaroma \\
\hline Aquadest & Ad 50 & $\operatorname{Ad} 50$ & Ad 50 & Ad 50 & Pelarut \\
\hline
\end{tabular}

\section{Uji evaluasi sedaiaan}

\section{a. Uji Organoleptis}

Pada sediaan yang telah diformulasi dilakukan pengamatan penampilan sediaan meliputi bau, warna dan tekstur sediaan.

b. Uji pH

Pengukuran $\mathrm{pH}$ sediaan dilakukan dengan menggunakan $\mathrm{pH}$ meter. Pemeriksaan $\mathrm{pH}$ diawali dengan kalibrasi alat $\mathrm{pH}$ meter menggunakan larutan dapar $\mathrm{pH}$ 7. Sebanyak $1 \mathrm{~g}$ sabun yang akan diperiksa diencerkan dengan air suling hingga $10 \mathrm{ml}$. Dimasukkan $\mathrm{pH}$ meter kedalam larutan sabun yang telah dibuat, kemudian ditunggu hingga indikator $\mathrm{pH}$ meter stabil dan menunjukkan nilai $\mathrm{pH}$ yang konstan.

\section{c. Uji ketinggian busa}

Prinsip kerja : $50 \mathrm{ml}$ larutan sabun $1 \%$ yang akan diuji dimasukan ke dalam air suling yang diteteskan pada ketinggian $90 \mathrm{~cm}$.

Cara kerja $50 \mathrm{ml}$ larutan sabun $1 \%$ yang akan di uji dimasukan ke dalam bejana gelas berupa gelas ukur $500 \mathrm{ml}$, ukur tingginya kemudian diteteskan $200 \mathrm{ml}$ larutan yang sama,dengan bantuan buret makrometer $50 \mathrm{ml}$,dengan ketinggian $90 \mathrm{~cm}$ di atas permukaan sabun,ukur tinggi busa yang terbentuk.

\section{d. Uji Hedonik}

Uji kesukaan konsumen dilakukan dengan metode uji organoleftis sejumlah 10 orang dimana masing-masing panelis diberikan sampel yaitu sabun cair ekstrak daun bidara arab dengan formula F1,F2,F3 yang akan mengisi kuisoner mengenai sabun tersebut (bentuk, bau, dan warna). Dengan kriteria Pria/Wanita berusia minimal 20 tahun, tidak sedang mengalami ganguan pada kulit seperti panu, kadas, kurap dan sebagainya, tidak ada riwayat penyakit kulit, tidak sedang dalam ganguan pernafasan

\section{e. Uji Viskositas}

Sampel yang diuji di tempatkan dalam wadah penampung bahan, wadah diatur ketinggiannya sehingga rotor dapat bergerak, dan mengunakan spindel 3 dengan kecepatan 50 rpm, kemudian rotor ditempatkan pada pengantungan dan diatur, sehingga diperoleh nilai viskositas pada sampel. 


\subsection{Hasil}

\section{HASIL DAN PEMBAHASAN}

Verifikasi tanaman di Laboratorium Biologi Universitas Bengkulu dengan membawa sampel tanaman bidara arab Ziziphus Spina-Christi L. hasil verifikasi menyatakan bahwa tanaman yang di gunakan dalam penelitian memang benar daun bidara arab dengan nama ilmiah Ziziphus Spina-Christi L yang disahkan dengan surat hasil verifikasi. Ekstrak daun bidara arab yang diperoleh dilakukan uji organoleptis berupa, bentuk sediaan, konsistensi, bau dan rasa. Pembuatan ekstrak daun bidara arab (Ziziphus Spiina-christi L.) dilakukan dengan cara maserasi menggunakan etanol $70 \%$ selama 6 hari. Pada sedian sabun cair ekstrak daun bidara arab dilakukan uji sifat fisik yakni, uji organoleptis, uji pH, uji ketinggian busa, dan uji hedonik yang dilakukan selama satu minggu penyimpanan, ini dilakukan bertujuan untuk mengamati perubahan yang terjadi pada sedian sabun cair setelah penyimpanan selama satu minggu. Hasil uji organoleptis dapat dilihat di Tabel 2.

Tabel 2. Hasil Uji Orgnoleptis Sabun Cair Ekstrak Daun Bidara Arab (Ziziphus Spina-christi L.)

\begin{tabular}{|c|c|c|c|c|}
\hline \multirow{2}{*}{$\mathbf{F}$} & \multirow{2}{*}{ Organoleptis } & \multicolumn{3}{|c|}{ Hari ke } \\
\hline & & I & IV & VII \\
\hline F0 & $\begin{array}{l}\text { Bentuk } \\
\text { Bau } \\
\text { Warna }\end{array}$ & $\begin{array}{l}\text { Kental } \\
\text { Apel } \\
\text { Kuning Pucat }\end{array}$ & $\begin{array}{l}\text { Kental } \\
\text { Apel } \\
\text { Kuning Pucat }\end{array}$ & $\begin{array}{l}\text { Kental } \\
\text { Apel } \\
\text { Kuning Pucat }\end{array}$ \\
\hline F1 & $\begin{array}{l}\text { Bentuk } \\
\text { Bau } \\
\text { Warna }\end{array}$ & $\begin{array}{l}\text { Kental } \\
\text { Apel } \\
\text { Coklat Muda } \\
\text { Kemerahan }\end{array}$ & $\begin{array}{l}\text { Kental } \\
\text { Apel } \\
\text { Coklat Muda } \\
\text { Kemerahan }\end{array}$ & $\begin{array}{l}\text { Kental } \\
\text { Apel } \\
\text { Coklat Muda } \\
\text { Kemerahan }\end{array}$ \\
\hline $\mathrm{F} 2$ & $\begin{array}{l}\text { Bentuk } \\
\text { Bau } \\
\text { Warna }\end{array}$ & $\begin{array}{l}\text { Kental } \\
\text { Apel } \\
\text { Coklat Sedang } \\
\text { Kemerahan } \\
\end{array}$ & $\begin{array}{l}\text { Kental } \\
\text { Apel } \\
\text { Coklat Sedang } \\
\text { Kemerahan } \\
\end{array}$ & $\begin{array}{l}\text { Sedikit cair } \\
\text { Apel } \\
\text { Coklat Sedang } \\
\text { Kemerahan }\end{array}$ \\
\hline F3 & $\begin{array}{l}\text { Bentuk } \\
\text { Bau } \\
\text { Warna }\end{array}$ & $\begin{array}{l}\text { Kental } \\
\text { Apel } \\
\text { Coklat Tua } \\
\text { Kemerahan }\end{array}$ & $\begin{array}{l}\text { Sedikit cair } \\
\text { Apel } \\
\text { Coklat Tua } \\
\text { Kemerahan }\end{array}$ & $\begin{array}{l}\text { Sedikit cair } \\
\text { Apel } \\
\text { Coklat Tua } \\
\text { Kemerahan }\end{array}$ \\
\hline
\end{tabular}

Keterangan:

$\mathrm{F} \quad=$ Formula

F0 = Formula sabun cair tanpa ekstrak daun bidara arab

$\mathrm{F} 1=$ Formula sabun cair dengan kadar ekstrak daun bidara arab $1 \%$

F2 = Formula sabun cair dengan kadar ekstrak daun bidara arab 3\%

F3 = Formula sabun cair dengan kadar ekstrak daun bidara arab 5\%

\section{Uji pH Sediaan Sabun Cair Ekstrak Daun Bidara Arab}

$\mathrm{pH}$ sediaan sabun cair sangat penting untuk memperbaiki dan meningkatkan kualitas kulit, selain itu juga sangat berpengaruh dalam meminimalkan iritasi pada kulit. Jika terlalu asam akan menyebabkan kulit kering, dan jika terlalu basa menyebabkan iritasi pada kulit. Adapun hasil pemeriksaan pH sabun cair ekstrak daun bidara arab (Ziziphus Spina-christi.L) Dapat dilihat pada Tabel 3.

Tabel 3. Uji pH Sabun Mandi Cair Ekstrak Daun Bidara Arab

\begin{tabular}{|l|l|l|l|}
\hline \multirow{2}{*}{ F } & Hari Ke & IV & VII \\
\cline { 2 - 4 } & I & 8,70 & 8,24 \\
\hline F0 & 9,97 & 8,23 & 7,88 \\
\hline F1 & 8,67 & 8,19 & 7,82 \\
\hline F2 & 8,64 & 7,97 & 7,59 \\
\hline F3 & 7,99 & \\
\hline
\end{tabular}




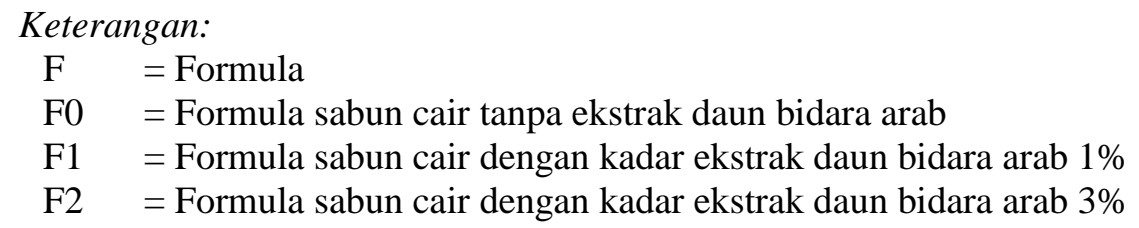

\section{Uji tinggi daya Busa}

Pengamatan tinggi busa dilakukan dengan cara menimbang 3 gr sediaan, larutkan dalam $50 \mathrm{ml}$ air ditambah $200 \mathrm{ml}$ air lalu masukkan dalam buret, buka keran buret aliri hingga larutan di dalam buret habis, lalu ukur ketinggian busa dengan penggaris. Rangkuman mengenai formulasi dan rata-rata tersebut teradapat pada Tabel 4.

Tabel 4. Uji tinggi Daya Busa Sabun Cair Ekstrak Daun Bidara Arab

\begin{tabular}{|l|l|}
\hline Formulasi & Rata rata $(\mathbf{c m})$ \\
\hline$F_{0}$ & 7,6 \\
\hline$F_{1}$ & 9,83 \\
\hline$F_{2}$ & 20 \\
\hline$F_{3}$ & 19 \\
\hline
\end{tabular}

\section{Uji Hedonik}

Setelah dilakukan uji hedonik (uji kesukaan) pada 10 orang panelis yang dipilih secara acak, dengan kriteria di bawah ini :

a. Pria/Wanita berusia minimal 20 tahun

b. Tidak sedang mengalami ganguan pada kulit seperti panu, kadas, kurap dan sebagainya

c. Tidak ada riwayat penyakit kulit

d. Tidak sedang dalam ganguan pernafasan

Kemudian hasil yang didapatkan atas penilaian terhadap keseluruhan formulasi sediaan sabun cair ekstrak daun bidara arab dapat dilihat pada Tabel 5

Tabel 5. Uji Hedonik Sabun Cair Eksrak Daun Bidara Arab (Ziziphus Spina-christi L.)

\begin{tabular}{|c|c|c|c|}
\hline \multirow{2}{*}{$\begin{array}{l}\text { Jumlah } \\
\text { panelis }\end{array}$} & \multirow{2}{*}{$\begin{array}{c}\text { Formulasi } \\
\text { sabun }\end{array}$} & \multicolumn{2}{|c|}{ Nilai Perlakuan } \\
\hline & & Suka & Tidak suka \\
\hline \multirow{3}{*}{10 orang } & F1 & 7 & 3 \\
\hline & F2 & 8 & 2 \\
\hline & F3 & 7 & 3 \\
\hline
\end{tabular}

Keterangan :

F1 = Formula sabun cair dengan kadar ekstrak daun bidara arab $1 \%$

F2 = Formula sabun cair dengan kadar ekstrak daun bidara arab 3\%

F3 = Formula sabun cair dengan kadar ekstrak daun bidara arab 5\%

\section{Uji Viskositas}

Sampel yang diuji di tempatkan dalam wadah penampung bahan, kemudian diatur ketinggianya sehingga rotor dapat bergerak. Dicari rotor yang sesuai dengan tingkat kekentalan pada sampel, yaitu rotor no $1: 0,3-15 \mathrm{P}$ (Poise), rotor no $2: 3-15 \mathrm{P}$ (Poise), dan rotor no 3 : 100 - 400 P (Poise) (Putra R, M, et al, 2016). Pada uji viskositas yang di lakukan mengunakan spindel 3 dengan kecepatan $50 \mathrm{rpm}$, sehingga diperoleh nilai viskositas dalamTabel 6 
Tabel 6. Uji Viskositas Sabun Cair Ekstrak Daun Bidara Arab (Ziziphus Spina-christi L.)

\begin{tabular}{|l|l|l|}
\hline No & Formula & Sampel \\
\hline 1 & F0 & 11,3 poise \\
\hline 2 & F1 & 11,6 poise \\
\hline 3 & F2 & 11,7 poise \\
\hline 4 & F3 & 11,8 poise \\
\hline
\end{tabular}

Dalam pembuatan ekstrak daun bidara arab, daun bidara arab yang digunakan seberat 937 gram, dibersihkan dari kotoran yang menempel, dirajang halus, lalu dikeringkan pada suhu kamar selama 6 hari dan didapat simplisia kering sebanyak 500 gram. Selanjutnya dilakukan maserasi dengan cara merendam simplisia sebanyak 500gram tersebut dengan etanol $70 \%$ sebanyak $2.000 \mathrm{ml}$ kedalam botol kaca gelap. Simplisia didiamkan selama 6 hari pada suhu kamar dengan sesekali dilakukan pengocokan lalu disaring untuk mendapatkan maserat. Maserat diperoleh dengan menggunakan waterbath hingga didapatkan ekstrak cair daun bidara arab sebanyak $29,4 \%$ selanjutnya dilakukan uji organoleptis ekstrak daun bidara arab yang bertujuan untuk mengetahui karakteristik sifat fisik dari ekstrak daun bidara arab berupa konsistensi, bau, dan warna.Pada penelitian yang dilakukan banyak ditemukan kandungan dalam daun bidara arab seperti fenol, alkaloid, flavonoid, tanin, saponin, [7] yang berguna sebagai antibakteri.

Pada penelitian ini proses pembuatan sabun yaitu larutan $\mathrm{KOH}$ sebanyak 8gram masukan ke dalam $16 \mathrm{ml}$ aquadest sedikit demi sedikit, aduk hingga larut. Setelah larut simpan di tempat aman dengan suhu ruangan hingga larutnya berubah menjadi jernih, Bahan-bahan yang telah disiapkan ditimbang sesuai dengan formula,Asam stearat dan nipasol dilebur, CMC dan SLS di larutkan terlebih dahulu kedalam air panas pada wadah yang berbeda. Panaskan minyak lalu masukkan larutan $\mathrm{KOH}$, masukkan $\mathrm{CMC}$ aduk hingga terbentuk massa sabun, Setelah terbentuk massa sabun, ditambahkan asam stearat dan nipasol kedalamnya diaduk hingga larut, tambahkan nipagin diaduk hingga larut. Setelah larut ditambahkan SLS, pengaroma dan ekstrak daun bidara arab sambil diaduk kembali hingga homogen, larutan diaduk terus menerus dengan cepat hingga terbentuk larutan yang kental, Pada larutan kental tersebut, kemudian tambahkan aquadest hingga volume $50 \mathrm{ml}$. Ekstrak daun bidara arab berfungsi sebagai zat aktif, $\mathrm{KOH}$, Asam Stearat, CMC berfungsi sebagai pengemulsi, SLS sebagai pembentuk busa, nipagin, nipasol sebagai pengawet, biang apel sebagai pengaroma, dan Aquadest sebagai pelarut.

Pada uji organoleptis sabun cair tidak adanya perbedaan pada bentuk dan bau sediaan namun, perbedaan yang sangat mencolok adalah pada warna masing-masing sediaan. Perubahan warna ini terjadi karena adanya pengaruh dari variasi konsentrasi zat aktif yang digunakan dalam formulasi, dimana zat aktif ekstrak daun bidara arab yang digunakan berwarna cokklat kemerahan, sehingga pada setiap variasi konsentrasi zat aktif terdapat perubahan warna untuk setiap formula. F0 berwarna kuning minyak karena tidak menggunakan penambahan zat aktif, sedangkan F1 berwarna coklat muda kemerahan dengan penambahan zat aktif esktrak daun bidara arab sebanyak 1\%, F2 berwarna coklat muda kemerahan dengan penambahan ekstrak sebanyak 3\%, dan F3 berwarna coklat tua kemerahan dengan penambahan zat aktif sebanyak $5 \%$. Semakin banyak zat aktif maka akan semakin pekat atau gelap warna sediaan. Sedangkan untuk bau, keempat formula tersebut tidak mengalami perubahan dan untuk bentuk mengalami perubahan di hari ke 7 pada formula 2 dan di hari ke 4 dan hari ke 7 pada formula 3 setelah dilakukan penyimpanan selama 3 minggu.

Dari uji $\mathrm{pH}$ yang telah dilakukan di peroleh hasil dari keempat formula menunjukkan $\mathrm{pH}$ yang cendrung basa, namun masih sesuai dengan persyaratan $\mathrm{pH}$ yang baik untuk sediaan sabun 
cair yaitu berkisar antara 8-11. Berdasarkan hasil $\mathrm{pH}$ yang diperoleh, setiap formulasi memiliki perbedaan $\mathrm{pH}$ namun tidak terlalu signifikan, perbedaan yang terjadi disebabkan oleh penambahan variasi konsentrasi ekstrak daun bidara arab dan penyimpanan yang dilakukan, dimana pada F0 tanpa penambahan ekstrak, F1 dengan penambahan ekstrak sebanyak 1\%, F2 3\%, dan F3 5\%. Semakin banyak variasi konsentrasi ekstrak yang ditambahkan maka $\mathrm{pH}$ formula menjadi semakin asam. Adapun $\mathrm{pH}$ dari ekstrak daun bidara arab yaitu berkisar 7,59,79 .

Berdasarkan tabel dan diagram dari hasil pengamatan yang dilakukan terhadap sediaan sabun cair ekstrak daun bidara arab, terlihat adanya pengaruh variasi konsentrasi dari zat aktif terhadap kemampuan daya busa dari masing-masing formula. Maka dari keempat formula dapat dilihat bahwa F2 memiliki daya busa yang paling baik dibandingkan dengan pengujian pada Formula lainnya yaitu dengan tinggi $21 \mathrm{~cm}$, akan tetapi dari semua formula yang telah dilakukan uji daya busa semua formula masuk dalam karakteristik busa sabun cair yang bagus (1,3-22 $\mathrm{cm})$. Berdasarkan perbedaan tinggi busa yang didapat maka, variasi konsentrasi ekstrak daun bidara arab mempengaruhi sifat fisik dari formulasi sabun cair yaitu pada stabilitas sabun cair tersebut.

Uji kesukaan disebut juga uji hedonik. Dalam uji hedonik panelis dimintakan tanggapan pribadinya tentang kesukaan atau sebaliknya yakni ketidaksukaan terhadap sabun cair. Uji hedonik ini meliputi empat sampel dengan F0 tanpa penambahan ekstrak, F1 1\% Penambahan ekstrak, F2 3\% penambahan ekstrak, dan F3 5\% penambahan ekstrak.

Uji hedonik (kesukaan) ini di lakukan setelah formula mengalami 2 minggu penyimpanan. Uji hedonik dilakukan terhadap 10 orang panelis yang dipilih secara acak, dengan cara memberikan kuisioner kepada masing-masing panelis. Selanjutnya panelis diberi penjelasan tentang cara pengisian kuisioner, dengan cara setiap orang panelis terlebih dahulu diminta untuk membaca intruksi yang ada didalam kuisioner. Setelah panelis paham, panelis dipersilakan untuk melihat sediaan secara organoleptis baik dari warna, bau, rasa dikulit maupun bentuknya. Panelis selanjutnya diberikan kebebasan untuk menilai dari masing-masing karakteristik sediaan. Dalam penilaian formula panelis diberikan intruksi untuk memberikan tanda ceklist $(\sqrt{ })$ hanya pada kolom yang mereka sukai dan tidak menyukainya.Dalam penilaian parapanelis tidak diperkenankan untuk mencontek penilaian terhadap panelis lainnya, panelis dituntut untuk menilai sesuai dengan keinginan panelis itu sendiri.

Dari hasil uji hedonik pada tabel diatas, terlihat adanya perbedaan terhadap penilaian dari masing-masing panelis. Perbedaan ini terjadi karena setiap panelis mempunyai pendapat mereka masing-masing sesuai dengan keinginan mereka sendiri, hal ini dikarenakan setiap panelis pasti memiliki kesukaan yang berbeda baik dari bentuk yang disukai, warna, bau bahkan rasa dikulit mereka sesuai dengan karakter yang mereka suka.

\section{KESIMPULAN}

Dari hasil penelitian, maka dapat diambil kesimpulan bahwa : Ekstrak dari Daun Bidara Arab (Ziziphus Spina-christi L.) dapat diformulasikan dalam bentuk sediaan sabun cair.Variasi konsentrasi kadar ekstrak dari Daun Bidara Arab (Ziziphus Spina-christi L.). setelah diformulasikan dalam bentuk sediaan sabun cair dapat mempengaruhi sifat fisik sediaan sabun cair secara organoleptis seperti warna, juga terhadap tinggi daya busa maupun $\mathrm{pH}$ dari sediaan sabun cair. serta formula ke dua adalah formula terbaik. 


\section{DAFTAR PUSTAKA}

[1] Tranggono, R., Latifah, F, 2008, Buku Pegangan Ilmu Pengetahuan Kosmetik, Gramedia Pustaka Utama, Jakarta

[2] Madigan,M, T,. Martinko, J.M,. Parker, J., 2008, Biology Of Microorganisms, 10th ed, University Carbondale, Southem. New York

[3] Hernani., bunasor, K.T., Fitriati., 2010, Formulasi Sabun Transparan Antijamur Dengan bahan Akif Ekstrak Lengkuas (Alpinia Galanga L.Swartz), Bul Littro, No.2 Vol.21, pp. 192-205 [online] available at http://ejurnal.litbang.pertanian.go.id/index.php/bultro/article/view/1876

[4] Rachmawati, F.J., Triyana, S.Y., 2008, Perbandingan Angka Kuman Pada Cuci Tangan Dengan Beberapa Bahan Sebagai Standarisasi Kerja Di Laboratorium Mikrobiologi Fakultas Kedokteran Universitas Islam Indonesia, Jurnal Logika Values Innovation Perfection No.1 Vol.5, pp.1-13 [online] available at https://journal.uii.ac.id/Logika/article/view/179/167

[5] Priyono, Agus., 2009, Makalah Pembuatan Sabun, Tugas Praktikum Semester, Fakultas Teknik, Universitas Riau

[6] Plastina, P., Bonofiglio, D., et all., 2012, Identification of Bioactive Constituents of Ziziphus Jujube Fruit Extracts Exerting Antiproliferative and Apoptotic Effect In Human Breast Cancer Cells, Journal Enthopharmacol, No.2 Vol.140 [online] available at https://www.ncbi.nlm.nih.gov/pubmed/22301448

[7] Kusriani, R.H., Nawawi, A., Machter, E., 2015, Penetapan Kadar Senyawa Fenolat Total Dan Aktivitas Antioksidan Ekstrak Daun, Buah, dan Biji Bidara (Ziziphus Spina-Christi L), Prosiding SNaPP: Kesehatan (Kedokteran, Kebidanan, Keperawatan, Farmasi, dan Psikologi), pp.311-318 [online] available at http://proceeding.unisba.ac.id/index.php/kesehatan/article/view/1364/pdf

[8] Dimpudus, S.A., Yamlean, P.V.Y., Yudistira, A., 2017, Formulasi Sediaan Sabun Cair Antiseptik Ekstrak Etanol Bunga Pacar Air (Impatiens Balsamina L) dan Uji Efektivitasnya Terhadap Bakteri Staphylococcus Aureus Secara In Vitro, Pharmacon Jurnal Ilmiah Farmasi, No.3 Vol.6, pp.208-215 [online] available at https://ejournal.unsrat.ac.id/index.php/pharmacon/article/view/16885/16408 